\title{
Nitrogen fertilization of coffee: organic compost and Crotalaria juncea L. $^{1}$
}

\author{
João Batista Silva Araujo², Mateus Cupertino Rodrigues ${ }^{3}$, Luisa Bastos Rodrigues ${ }^{3}$, \\ Ricardo Henrique Silva Santos ${ }^{4}$, Herminia Emilia Prieto Martinez ${ }^{4}$
}

\begin{abstract}
Information concerning the response of coffee to organic fertilizers is scarce. This study evaluates the effect of different doses of compost and Crotalaria juncea L. on growth, production and nitrogen nutrition of coffee trees. The treatments consisted of compost at rates of 25, 50, 75 and $100 \%$ of the recommended fertilization, with or without the aerial part of $C$. juncea. $C$. juncea was grown with $\mathrm{NH}_{4}-\mathrm{N}\left(2 \%{ }^{15} \mathrm{~N}\right)$ and applied to coffee. The use of $C$. juncea increased growth in height and diameter of the coffee canopy. In the first year, the percentage of $\mathrm{N}$ derived from $C$. juncea reached $8.5 \%$ at seven months and $4.1 \%$ at fifteen months after fertilization. In the second year, the percentage of $\mathrm{N}$ derived from $C$. juncea reached $17.9 \% \mathrm{~N}$ at the early harvest, five months after fertilization. Increased rates of compost increased $\mathrm{pH}, \mathrm{P}, \mathrm{K}, \mathrm{Ca}, \mathrm{Mg}$, sum of bases , effective CEC, base saturation and organic matter and reduced potential acidity. ${ }^{15} \mathrm{~N}$ allowed the identification of the $\mathrm{N}$ contribution from $C$. juncea with percentage of leaf $\mathrm{N}$ derived from Crotalaria juncea from 9.2 to $17.9 \%$.
\end{abstract}

Key words: Crotalaria juncea L., green manure, organic fertilizer, ${ }^{15} \mathrm{~N}$.

\section{RESUMO}

\section{Adubação nitrogenada de cafeeiros com composto e crotalária}

A resposta do cafeeiro aos adubos orgânicos é pouco estudada e, por isso, objetivou-se, neste trabalho, avaliar o efeito de diferentes doses de composto e de Crotalaria juncea L. sobre o crescimento, a produção e a nutrição nitrogenada dos cafeeiros. Os tratamentos foram: composto orgânico, nas doses de 25, 50, 75 e $100 \%$ da adubação recomendada, com ou sem a parte aérea de C. juncea. A C. juncea foi cultivada com $\mathrm{N}_{-} \mathrm{NH}_{4}\left(2 \%\right.$ de $\left.{ }^{15} \mathrm{~N}\right)$ e aplicada nos cafeeiros. A crotalária promoveu maior crescimento em altura e diâmetro de copa do cafeeiro. No $1^{\circ}$ ano, o percentual de $\mathrm{N}$ derivado da crotalária atingiu $8,5 \%$ aos sete meses e $4,1 \%$, aos quinze meses após a adubação. No $2^{\circ}$ ano, foram atingidos $17,9 \%$ de $\mathrm{N}$ derivado da crotalária no início da colheita, cinco meses após a adubação. O aumento das doses de composto promove a elevação do $\mathrm{pH}, \mathrm{P}, \mathrm{K}, \mathrm{Ca}, \mathrm{Mg}$, Soma de bases, CTCefetiva, saturação de bases e matéria orgânica, e redução da acidez potencial. O uso do isótopo ${ }^{15} \mathrm{~N}$ permite a identificação da contribuição do $\mathrm{N}$ derivado da crotalária para o cafeeiro, com percentuais foliares de N derivado de Crotalaria juncea de 9,2 a 17,9\%.

Palavras-chave: Crotalaria juncea L., adubação verde, adubação orgânica, ${ }^{15} \mathrm{~N}$.

Received: 26/02/2013; Accepted: 31/07/2013.

'Part of the first author's Doctoral Thesis. Research funded by CNPq

${ }^{2}$ Agronomist Engineer, Doctor of Science. INCAPER Instituto Capixaba de Pesquisa, Assistência Técnica e Extensão Rural, Rodovia BR 262, Km 95, 29375-000, Venda Nova do Imigrante, Espírito Santo, Brasil. Bolsita FAPES. jaraujo_vni@yahoo.com.br (corresponding author).

${ }^{3}$ Undergraduates in Agronomy. Universidade Federal de Viçosa, Campus Viçosa, Avenida Peter Henry Rolfs, s/n, 36570-000, Viçosa, Minas Gerais, Brasil. mateus.rodrigues@ ufv.br; luisa.rodrigues@ufv.br (Bolsistas IC - CNPq.).

${ }^{4}$ Agronomist Engineers, Doctors of Science. Departamento de Fitotecnia, Universidade Federal de Viçosa, Campus Viçosa, Avenida Peter Henry Rolfs, s/n, 36570-000, Viçosa, Minas Gerais, Brasil.rsantos@ufv.br; herminia@ufv.br 


\section{INTRODUCTION}

Green manure and compost fertilizations are common practices in agro-ecological coffee production, but despite the potential benefits of organic fertilizers (Ricci et al., 2005; Bergo et al., 2006), there is little information on the response of coffee trees to these fertilizers. Compost increases foliar $\mathrm{N}$ with increasing rates (Araujo et al., 2007). It also replaces $\mathrm{N}$ and $\mathrm{K}$ from mineral sources in coffee during the formation phase, promoting growth similar to the mineral fertilization in number of nodes and branches, leaf area and leaf dry matter (Araujo et al., 2008) .

The legume production in situ allows the complementation of fertilization by the input of N-BNF (N from Biological Nitrogen Fixation) in the productive system. This complementation with $C$. juncea was reported for corn (Silva et al., 2006) and sugarcane (Ambrosano et al., 2011) and wit early or late legume species in grapevine (Ovalle et al., 2010).

$\mathrm{N}$ levels are also influenced by legume species. There are reports of lower leaf $\mathrm{N}$ content in coffee intercropped with Crotalaria juncea compared with the monocrop (Ricci et al., 2005), as well as similar leaf $\mathrm{N}$ in coffee fertilized with gray velvet bean (aerial parts) and ammonium sulfate, although the application of leucaena, pigeon pea, perennial peanut, brachiaria or sorghum has resulted in lower levels than those obtained with application of ammonium sulfate (Fidalsky \& Chaves, 2010).

The application of legumes (aerial parts) produced in other areas allows the nutritional study and fertilizing potential without the interference effect of the intercropping (Fidalsky \& Chaves, 2010; Vilela et al., 2011). There are reports of increased growth and yield of coffee trees that received legume biomass compared with those obtained with ammonium sulfate (Fidalsky \& Chaves, 2010; Vilela et al , 2011).

Although green manure is known as $\mathrm{N}$ source, studies that determine the percentage of $\mathrm{N}$ present in coffee derived from legumes are scarce. Snoeck et al., (2000) reported that $42.3 \%$ of $\mathrm{N}$ in coffee was originated from Leucaena leucocephala (Lam) de Wit. There are reports of legume contribution of legumes to nitrogen nutrition in other crops. The application of $C$. juncea in maize resulted in $45.4 \%$ of $\mathrm{N}$ derived from the aerial part of the legume used as the sole fertilizer and 23.4 to $16.5 \%$ when supplemented with different doses of urea (Silva et al., 2009a). In grapevine, 14 to $20 \%$ of leaf $\mathrm{N}$ derived from early and late intercropped pulses, respectively (Ovalle et al., 2010).

Direct determination of $\mathrm{N}$ derived from legumes uses isotopic enrichment of green manure, which allows increasing the ${ }^{15} \mathrm{~N}$ concentration above the natural abundance of ${ }^{15} \mathrm{~N}$ in the air and, thus, to use the isotope as a tracer. The labeling strategy is to grow the green manure in a controlled environment in order to inhibit the biological fixation and uptake of the ${ }^{15} \mathrm{~N}$-fertilizer to achieve the desired isotopic labeling (Ambrosano et al., 2003).

Despite some recent studies, little is known about the effect of different organic fertilizer rates and their complementation with green manure. Therefore, we aimed to evaluate the initial growth, yield and content of $\mathrm{N}$ derived from green manure (NfGM) in Arabic coffee fertilized with different rates of compost, supplemented with Crotalaria juncea.

\section{MATERIALS AND METHODS}

The experiment was conducted at the Federal University of Viçosa, MG, located at $20^{\circ} 45^{\prime} 14^{\prime \prime} \mathrm{S}$ and $42^{\circ}$ 52' 53' O, $650 \mathrm{~m}$ altitude. The region has a cold and dry winter, hot and rainy summer with average temperature of $19.4{ }^{\circ} \mathrm{C}$ (maximum $26.4{ }^{\circ} \mathrm{C}$ and minimum $14.8^{\circ} \mathrm{C}$ ) and average rainfall of $1.221 \mathrm{~mm}$ per year.

The experimental design was a 4x2 factorial arrangement with four levels of organic fertilizer $(25,50$, 75 and $100 \%$ ) and two rates of Crotalaria juncea ( 0 and $450 \mathrm{~g} / \mathrm{plant}$ ) in a randomized block design with four replications. The plots contained nine plants, considering seven useful plants.

Seedlings of Coffeea arabica $\mathrm{cv}$. Oeiras were planted in February 2009 in a spacing of $2.0 \times 0.75 \mathrm{~m}$. Initially, the soil characteristics were: $1.4 \mathrm{~g} \mathrm{~kg}^{-1}$ of organic matter; $\mathrm{pH}$ $\left(\mathrm{H}_{2} \mathrm{O}\right) 5.2 ; 8.0 \mathrm{mg} \mathrm{dm}^{-3} \mathrm{P} ; 50 \mathrm{mg} \mathrm{dm}^{-3} \mathrm{~K} ; 2.0 \mathrm{cmol}_{\mathrm{c}} \cdot \mathrm{dm}^{-3} \mathrm{Ca}^{2+}$; $0.8 \mathrm{cmol} . \mathrm{dm}^{-3} \mathrm{Mg}^{2+} ; 0.3 \mathrm{cmol} \cdot \mathrm{dm}^{-3} \mathrm{~A}^{13+} ; 3.80 \mathrm{cmol} \cdot \mathrm{dm}^{-3} \mathrm{H}$ $+\mathrm{A}^{13+} ; 2.93 \mathrm{cmol}_{\mathrm{c}} \cdot \mathrm{dm}^{-3}$ sum bases; $3.23 \mathrm{cmol}_{\mathrm{c}} \cdot \mathrm{dm}^{-3}$ effective CEC; $6.73 \mathrm{cmol}_{\mathrm{c}} \cdot \mathrm{dm}^{-3}$ total CEC; $44 \%$ of base saturation and $32.6 \mathrm{mg} \mathrm{L}^{-1}$ P-rem. Planting holes received $0.165 \mathrm{~kg}$ of lime, $0.286 \mathrm{~kg}$ of Gafsa rock phosphate, $0.03 \mathrm{~kg}$ of FTE BR 11. The rate of $100 \%$ chicken manure at transplanting corresponded to $0.07 \mathrm{~kg} /$ hole of $\mathrm{N}$. Poultry litter had $\mathrm{pH}$ $\left(\mathrm{H}_{2} \mathrm{O}\right)$ of $7.69 ; 52.9 \%$ moisture; $\mathrm{C} / \mathrm{N}$ ratio 10.4 and levels of $20.74 \mathrm{~g} \mathrm{~kg}^{-1}$ of organic carbon (OC); $19.9 \mathrm{~g} \mathrm{~kg}^{-1} \mathrm{~N} ; 14.4 \mathrm{~g}$ $\mathrm{kg}^{-1} \mathrm{P} ; 28.8 \mathrm{~g} \mathrm{~kg}^{-1} \mathrm{~K} ; 35.3 \mathrm{~g} \mathrm{~kg}^{-1} \mathrm{Ca} ; 6.4 \mathrm{~g} \mathrm{~kg}^{-1} \mathrm{~S}$, which were determined according to Silva (2009c).

\section{Production of labeled $\mathrm{C}$. juncea $\left({ }^{15} \mathrm{~N}-\mathrm{Cj}\right)$ and unlabeled $C$. juncea $(\mathrm{Cj})$}

$\mathrm{Cj}$ was grown in the field, without lime and fertilizers, spaced $0.5 \mathrm{~m}$ apart with 30 seeds per meter. The first cultivation took place from $22 / 11 / 2009$ to $25 / 01 / 2010$ and the second, from 05/10/2010 to 22/12/2010.

${ }^{15} \mathrm{~N}-\mathrm{Cj}$ was grown in a greenhouse in the same period, in 500-L fiberglass boxes. The seeds were immersed in $1 \%$ sodium hypochlorite for 5 minutes, then $70 \%$ ethanol for 1 minute, washed with distilled water and sown. Each box was filled with $260 \mathrm{~L}$ of the substrate washed sand and vermiculite $1: 1$, fertilized with $300 \mathrm{mg} \mathrm{dm}^{-3}$ of $\mathrm{P}_{2} \mathrm{O}_{5}, 29 \mathrm{mg}$ $\mathrm{dm}^{-3} \mathrm{~K}$ and $130 \mathrm{mg} \mathrm{dm}^{-3}$ ( $\mathrm{N}$ ammonium sulfate with $2 \%{ }^{15} \mathrm{~N}$ a.e.). The ratio of $\mathrm{Ca}$ and $\mathrm{Mg}$ was 3:1. The application of $\mathrm{N}$ 
and $\mathrm{K}$ was split at $5,12,19,25,33,37,41$ and 57 days after sowing. Micronutrients were applied via Hoagland and Arnon (1950) solution, according to Martinez \& Clemente (2011), in the following formulation: $\mathrm{B}=46 \mu \mathrm{mol} \mathrm{L}^{-1}$; $\mathrm{Cu}=0.3 \mu \mathrm{molL}^{-1} ; \mathrm{Fe}+\mathrm{EDTA}=45 \mu \mathrm{mol} \mathrm{L}^{-1} ; \mathrm{Mn}=12.6 \mu \mathrm{mol}$ $\mathrm{L}^{-1} ; \mathrm{Mo}=0.1 \mu \mathrm{mol} \mathrm{L}^{-1}$ and $\mathrm{Zn}=1.3 \mu \mathrm{mol} \mathrm{L}^{-1}$, completing the volume to $1000 \mathrm{~mL}$ with distilled water, applying 0.5 $\mathrm{mL} \mathrm{dm}{ }^{-3}$ substrate.

Four samples of ${ }^{15} \mathrm{~N}-\mathrm{Cj}$ and $\mathrm{Cj}$ were weighed at harvest, dried in an oven at $65^{\circ} \mathrm{C}$ to constant biomass and ground. $\mathrm{N}$ content was determined by the Kjeldahl method. ${ }^{15} \mathrm{~N}-\mathrm{Cj}$ samples were powdered in a rolling mill for 24 hours for ${ }^{15} \mathrm{~N}$ determination using a biomass spectrometer (Finnigan Mat Delta Plus), Nitrogen Laboratory of Embrapa Agrobiology.

\section{C. juncea decomposition}

Fresh matter samples of $0.20 \mathrm{~kg}$ of $C$. juncea were placed on the ground under the coffee canopy, covered with $0.30 \times 0.30 \mathrm{~m}$ screens of $4 \times 4 \mathrm{~mm}$ mesh and collected after $0,3,7,12,18,25,32,40$ and 60 days. The samples were collected and dried at $65^{\circ} \mathrm{C}$ up to constant mass in an oven with forced air circulation, weighed, ground and $\mathrm{N}$ content was determined by the Kjeldahl method.

Decomposition rates of dry matter and $\mathrm{N}$ mineralization of the green manure were determined by nonlinear regression models, as described by Wieder \& Lang (1982), as cited by Aita \& Giacomini (2003). The asymptotic model has the following equation:

$\mathrm{DMR}$ or $\mathrm{NR}=\mathrm{Ae}^{-\mathrm{kat}}$

where: DMR and NR correspond to the percentage of dry matter and nitrogen remaining at time $t$; $t$ is the sampling time from 0 to 60 days; $\mathrm{ka}$ is the constant rate of decomposition of dry matter and $\mathrm{N}$ mineralization. DMR and NR were calculated relative to DM and $\mathrm{N}$ at time zero for each sampling time. From the decomposition constants of DMR or NR, it was calculated the half-life $\left(\mathrm{t}_{1 / 2}\right)$ required for $50 \%$ of the dry matter or $\mathrm{N}$ to be mineralized to the soil, using the equation $\left(\mathrm{t}_{1 / 2}\right)=\ln 0.5 / \mathrm{k}$, according to Paul \& Clark (1996). The rainfall for the period was $58 \mathrm{~mm}$ (Jan), $45 \mathrm{~mm}$ (Feb) and $185 \mathrm{~mm}$ (Mar) and $28 \mathrm{~mm}$ (Apr).

\section{Fertilization with $C$. juncea}

$\mathrm{Cj}$ was applied to the useful plants of the plot and ${ }^{15} \mathrm{~N}$ $\mathrm{Cj}$ was applied to microplots containing two coffee trees on 29/01/2010 and 21/12/2010 (Figure 1). Each plot had two microplots (M1 and M2), one for each year of the application of labeled $C$. juncea. The plots were fenced with galvanized steel plates, $0.5 \mathrm{~m}$ high, buried $0.45 \mathrm{~m}$ deep, in an area of $2.0 \times 1.5 \mathrm{~m}$. The level of $\mathrm{N}-\mathrm{Cj}$ was 13.41 $\mathrm{g} \mathrm{kg}^{-1}$ of N in the 1st crop year (2009/2010) and $17.45 \mathrm{~g} \mathrm{~kg}^{-1}$ in the 2nd crop year (2010/2011).

\section{Topdressing}

The organic compost was prepared in $60 \%$ elephant grass, $20 \%$ of coffee husk and $20 \%$ of poultry litter. The application was in a single dose. In November 2009 (Figure 1), the rate $100 \%$ of compost corresponded top $0.03 \mathrm{~kg} /$ plant $\mathrm{N}$ according to the recommendation of Guimarães $e t$ al. (1999) and, in November 2010, it was calculated for the expected production of $20 \mathrm{bags} \mathrm{ha}^{-1}\left(1200 \mathrm{~kg} \mathrm{ha}^{-1}\right)$, which corresponded to $0.021 \mathrm{~kg} / \mathrm{plant}$ of $\mathrm{N}$. The compost used in November 2009 had pH $\left(\mathrm{H}_{2} \mathrm{O}\right) 9.13 ; 17.95 \mathrm{C} / \mathrm{N} ; 226.5 \mathrm{~g}$ $\mathrm{kg}^{-1}$ organic carbon; $12.6 \mathrm{~g} \mathrm{~kg}^{-1} \mathrm{~N} ; 16.2 \mathrm{~g} \mathrm{~kg}^{-1} \mathrm{P} ; 24.0 \mathrm{~g} \mathrm{~kg}^{-1}$ $\mathrm{K} ; 77.0 \mathrm{~g} \mathrm{~kg}^{-1}$ of Ca; $5.2 \mathrm{~g} \mathrm{~kg}^{-1} \mathrm{Mg} ; 4.8 \mathrm{~g} \mathrm{~kg}^{-1} \mathrm{~S}$, wich were determined according to Silva (2009c). The compost used in November 2010 had $\mathrm{pH}\left(\mathrm{H}_{2} \mathrm{O}\right) 9.46 ; 168.3 \mathrm{~g} \mathrm{~kg}^{-1}$ organic carbon; C/ N 8.05; $20.9 \mathrm{~g} \mathrm{~kg}^{-1} \mathrm{~N} ; 24.4 \mathrm{~g} \mathrm{~kg}^{-1} \mathrm{P} ; 25.6 \mathrm{~g} \mathrm{~kg}^{-1} \mathrm{~K}$; $110.3 \mathrm{~g} \mathrm{~kg}^{-1} \mathrm{Ca} ; 7.6 \mathrm{~g} \mathrm{~kg}^{-1} \mathrm{Mg}$; and $7.0 \mathrm{~g} \mathrm{~kg}^{-1} \mathrm{~S}$.

\section{Growth evaluation}

Total growth of coffee trees was evaluated through height $(\mathrm{H})$ and crown diameter $(\mathrm{CD})$. The upper crown was evaluated: a tape was used to mark the second internode from the apex of the plant. Above the marked internode, we measured height $(\mathrm{Hm})$, the number of plagiotropic branches (NPBm) and nodes of the orthotropic branch (NNOm). In the plagiotropic branches of the marked internode we measured length (LPBm) and recorded the number of nodes (NNPm), reproductive nodes (NRNm) and leaves (NLPm). Markers were placed on 24/04/2010 and measurements of H, Hm, NPBm, NNOm and CD were taken on 7/11/10 and 19/04/11 (Figure 1), while LPBm, NNPm, NRNm and NLPm were taken on 20/ $11 / 10$ and 22/04/11.

\section{Coffee harvest and soil characteristics}

Harvest was carried out in May and June 2011, in coffee trees with over $50 \%$ of ripe fruit (visual evaluation). Samples of $2.0 \mathrm{~kg}$ of each picking were placed in jute bags, dried in a shed drying patio to $12 \%$ moisture and processed. Soil samples were collected (0-0.20 $\mathrm{m}$ deep) in the canopy projection of the coffee trees, in September 2011. The composite samples were obtained from seven subsamples, corresponding to the useful plants of each plot. The analyses were performed according to Silva (2009c).

\section{Leaf sampling}

Samples of the 3rd or 4th pair of leaves were collected from the apex of the plagiotropic branch in the middle third of the coffee tree in April, June and December 2010 and in April 2011 (Figure 1). Drying of leaves and determinations of $\mathrm{N}$ and $\mathrm{N}$ derived from green manure NfGM were the same as described for $C$. juncea. The estimated recovery of NfGM was obtained by the following equation: 
NfGM $\%=\left(\%{ }^{15} \mathrm{~N}\right.$ a.e. in coffee $/ \%{ }^{15} \mathrm{~N}$ a.e. in leg $) \times 100$,

Where: ${ }^{15} \mathrm{~N} \%$ a.e. in coffee is the atom percent excess in coffee leaves and $\%{ }^{15} \mathrm{~N}$ a.e. in leg is the atom percent excess in C. juncea.

\section{Statistical analyzes}

Data of growth, production, soil, $\mathrm{N}$ content and the percentages of NfGM were subjected to analysis of variance at $5 \%$ probability. The response to the factor rates of compost and the variables of $C$. juncea decomposition were analyzed by regression analysis.

\section{RESULTS}

\section{C. juncea decomposition}

At day 60, the remaining dry matter of $C$. juncea corresponded to $66.4 \%$ of the original mass (Table 1 ) and $\mathrm{T}_{1 / 2}$ was estimated at 96.3 days. $\mathrm{T}_{1 / 2}$ of $\mathrm{N}$ was estimated at 33.3 days and $69.1 \%$ of $\mathrm{N}$ was mineralized up to 60 days, which corresponds to the release of $20.2 \mathrm{~kg} \mathrm{ha}^{-1}$ and 27.8 $\mathrm{kg} \mathrm{ha}^{-1}$, respectively.

\section{Growth and production}

There was a significant effect of $C$. juncea fertilization between November 2010 and April 2011 on H, Hm and CD ( $\mathrm{p}<0.05)$, both in total growth, until April 2011 (B), and in the increase between November 2010 and April 2011 (BA)
(Table 2). There was significant effect $(\mathrm{p}<0.05)$ of compost on $\mathrm{CD}$, with an increase of almost $0.1 \mathrm{~cm}$ for every $1.4 \mathrm{~kg}$ $\mathrm{N} \mathrm{ha}^{-1}$ (Table 1). There was no significant effect of compost rates and $C$. juncea on coffee yield $(\mathrm{p} \leq 0.05)$, with mean of 7.9 bags ha $^{-1}(\mathrm{~s}=2.94-7.9 \mathrm{bags}=474 \mathrm{~kg})$.

\section{Soil Characteristics}

There was effect of compost for all variables of $C$. juncea, on the $\mathrm{H}+\mathrm{Al}$ content and interaction of factors on total CEC ( $p$ < 0.05) (Table 3). Increased rates of compost increased $\mathrm{pH}, \mathrm{P}, \mathrm{K}, \mathrm{Ca}, \mathrm{Mg}$, sum of bases, effective CEC, base saturation and organic matter and reduced the potential acidity (Table 1). There was effect of compost unfolding for each level of $C$. juncea $(\mathrm{p}<0.05)$ on total CEC, with linear increase of the levels without $C$. juncea (Table 1). The unfolding of the $C$. juncea rate within each level of compost showed an increase in total CEC with addition of $C$. juncea at the rates 25 and $75 \%$ of compost (Table 3). The use of $C$. juncea biomass decreased the potential acidity from 2.03 to $1.84 \mathrm{cmol} \mathrm{cm}^{-3}$, indicating that the legume promoted the increase of bases in the soil exchange complex, since the aluminum content of the soil was null (Table 1).

\section{Leaf $N$ at sampling dates}

There was significant effect $(\mathrm{p}<0.05)$ in Apr/2010 due to $C$. juncea, in Jun/2010 and Apr/2011 due to the compost

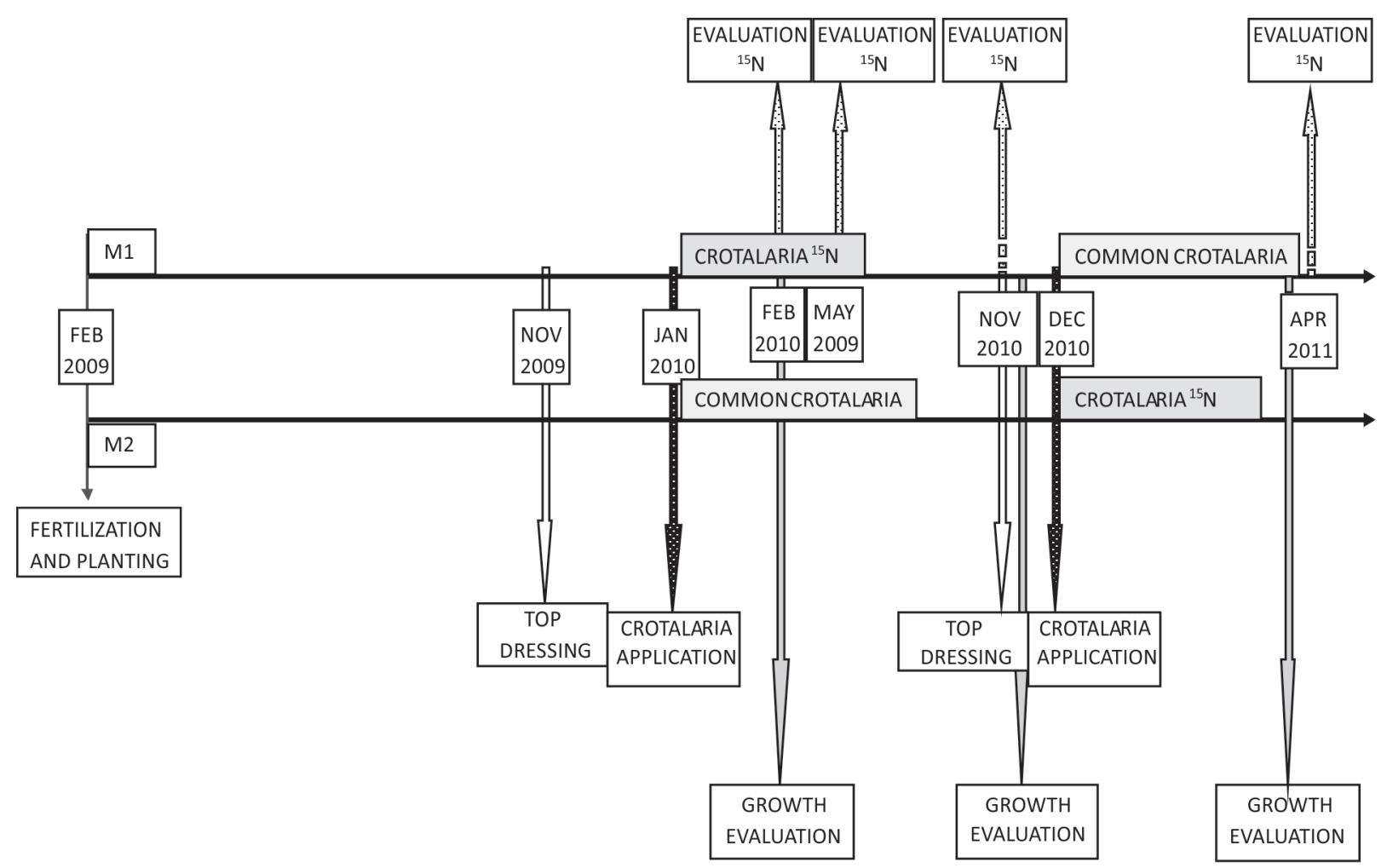

Figure 1. Chronology of organic fertilizer application at planting and topdressing, Crotalaria juncea conventional or labeled with ${ }^{15} \mathrm{~N}$ to microplots in the years 1 and 2 (M1 and M2) and the evaluation times. 
and in Dec/2010, because of the interaction of the factors (Table 4). In April 2010, leaf N concentration was higher with $C$. juncea, indicating a supplementary effect to the compost, which did not occur on the following dates. Leaf contents increased with compost rates, from 2.47 to $2.82 \%$ in June 2010 and 1.91 to 2.22\% in April 2011 (Table 4), promoting increases of 14 and $17 \%$, respectively.
In the unfolding of $C$. juncea levels, within each compost rate, the supplementary fertilization with $C$. juncea reduced leaf $\mathrm{N}$ in the rates $25 \%$ and $50 \%$ of compost $\mathrm{N}$, and increased leaf $\mathrm{N}$ in the rate $100 \%$ (Table 4). In the unfolding of the effect of compost rates, within each level of C. juncea in November 2010, the leaf $\mathrm{N}$ concentration decreased with increasing compost rates (Table 1),

Table 1. Regression equations and coefficients of determination for estimates of dry matter and $\mathrm{N}$ remaining from Crotalaria juncea, crown diameter, soil variables, leaf $\mathrm{N}$ and leaf $\mathrm{N}$ percentage derived from green manure (NfGM) in coffee fertilized with different rates of organic compost (x)

\begin{tabular}{|c|c|c|c|}
\hline Variables & Date & Equation & $\mathbf{r}^{2}$ \\
\hline Remaining dry matter & - & $\hat{y}=102.2243 \mathrm{e}^{-0.0071 x}$ & 0.7960 \\
\hline Remaining nitrogen & - & $\hat{y}=113.3307 \mathrm{e}^{-0.0217 x}$ & 0.9280 \\
\hline Crown diameter $(\mathrm{cm})$ & Apr/2011 & $\hat{\mathrm{y}}=91.52+0.4665^{* * x}$ & 0.8882 \\
\hline $\mathrm{pH}$ & Jan/2012 & $\hat{\mathrm{y}}=6.3687+0.00570 * * \mathrm{x}$ & 0.8664 \\
\hline $\mathrm{P}\left(\right.$ dag $\left._{\mathrm{kg}}{ }^{-1}\right)$ & $\mathrm{Jan} / 2012$ & $\hat{y}=104.2500+3.66000 * * x$ & 0.9606 \\
\hline $\mathrm{K}\left(\right.$ dag kg $\left.^{-1}\right)$ & Jan/2012 & $\hat{y}=414.4375+2.22000 * * x$ & 0.9373 \\
\hline $\mathrm{Ca}\left(\mathrm{cmol}_{\mathrm{c}} \mathrm{dm}^{-3}\right)$ & $\mathrm{Jan} / 2012$ & $\hat{\mathrm{y}}=2.5062+0.01180 * * \mathrm{x}$ & 0.9775 \\
\hline $\operatorname{Mg}\left(\mathrm{cmol}_{\mathrm{c}} \mathrm{dm}^{-3}\right)$ & $\mathrm{Jan} / 2012$ & $\hat{\mathrm{y}}=0.5187+0.00225^{* *} \mathrm{x}$ & 0.8224 \\
\hline $\mathrm{H}+\mathrm{Al}\left(\mathrm{cmol}_{\mathrm{c}} \mathrm{dm}^{-3}\right)$ & $\mathrm{Jan} / 2012$ & $\hat{y}=2.3375-0.00620 * * x$ & 0.8196 \\
\hline $\mathrm{SB}$ and $\mathrm{t}\left(\mathrm{cmol}_{\mathrm{c}} \mathrm{dm}^{-3}\right)$ & $\mathrm{Jan} / 2012$ & $\hat{y}=4.0125+0.02030 * * x$ & 0.9876 \\
\hline $\mathrm{CEC}_{\text {total }}$ (without $C$. juncea $)\left(\mathrm{cmol}_{\mathrm{c}} \mathrm{dm}^{-3}\right)$ & $\operatorname{Jan} / 2012$ & $\hat{y}=5.8625+0.02210 * * x$ & 0.8287 \\
\hline $\mathrm{CEC}_{\text {total }}($ with $C$. juncea $)\left(\mathrm{cmol}_{\mathrm{c}} \mathrm{dm}^{-3}\right)$ & $\mathrm{Jan} / 2012$ & $\hat{y}=7.5025$ & - \\
\hline $\mathrm{V}(\%)$ & $\operatorname{Jan} / 2012$ & $\hat{\mathrm{y}}=60.5625+0.16500 * * x$ & 0.9476 \\
\hline $\mathrm{OM}\left(\mathrm{mg} \mathrm{dm}^{-3}\right)$ & Jan/2012 & $\hat{\mathrm{y}}=1.69375+0.00790 * * x$ & 0.9986 \\
\hline $\mathrm{N}(\%)$ & $\mathrm{Jul} / 2010$ & $\hat{\mathrm{y}}=2.3583+0.0218 * * \mathrm{x}$ & 0.9254 \\
\hline $\mathrm{N}$ without $C$. juncea $(\%)$ & Dec/2010 & $\hat{\mathrm{y}}=3.0645-0.0355^{* *} \mathrm{x}$ & 0.8276 \\
\hline $\mathrm{N}$ with $C$. juncea $(\%)$ & Dec/2010 & $\hat{\mathrm{y}}=2.5111$ & - \\
\hline NfGM & Apr/2011 & $\hat{\mathrm{y}}=1.803+0.0198^{* *} \mathrm{x}$ & 0.9227 \\
\hline
\end{tabular}

** Significant at $1 \%$ probability by t test.

$\mathrm{N}$ doses of the organic compound in Nov/2010 : $5.25,10.50,15.75$ and $21.00 \mathrm{~g} / \mathrm{plant}$.

Table 2. Coffee growth under two rates of Crotalaria juncea aerial parts, 24/April/2010, evaluations in November/2010 (A) and April/2011 (B), and increase between the two dates (B-A)

\begin{tabular}{|c|c|c|c|c|c|c|c|c|}
\hline $\begin{array}{l}\text { C. } \text { juncea }^{1} \\
\text { (g/plant) }\end{array}$ & $\begin{array}{c}\mathbf{H} \\
(\mathbf{c m})\end{array}$ & $\begin{array}{l}\mathrm{Hm} \\
(\mathrm{cm})\end{array}$ & NPBm & NNOm & $\begin{array}{l}\text { CD } \\
(\mathbf{c m})\end{array}$ & $\begin{array}{c}\text { LPBm } \\
(\mathrm{cm})\end{array}$ & NRNm & NLPm \\
\hline \multicolumn{9}{|c|}{ A:Apr-Nov/2010 } \\
\hline 0 & $55.51 \mathrm{a}$ & $10.95 \mathrm{a}$ & $8.58 \mathrm{a}$ & $5.66 \mathrm{a}$ & $58.97 \mathrm{a}$ & $12.18 \mathrm{a}$ & $5.60 \mathrm{a}$ & $9.91 \mathrm{a}$ \\
\hline 450 & $56.01 \mathrm{a}$ & $10.99 \mathrm{a}$ & $9.00 \mathrm{a}$ & $5.75 \mathrm{a}$ & $59.48 \mathrm{a}$ & $12.12 \mathrm{a}$ & $5.42 \mathrm{a}$ & $10.01 \mathrm{a}$ \\
\hline$\overline{\mathrm{CV}(\%)}$ & 9.65 & 16.47 & 12.23 & 7.81 & 13.45 & 12.48 & 7.17 & 8.23 \\
\hline \multicolumn{9}{|c|}{ B: Nov-Apr/2011 } \\
\hline 0 & $84.84 \mathrm{a}$ & $42.97 \mathrm{a}$ & $21.52 \mathrm{a}$ & $13.35 \mathrm{a}$ & $94.33 \mathrm{a}$ & $37.13 \mathrm{a}$ & $11.44 \mathrm{a}$ & 16.44 \\
\hline 450 & $89.93 \mathrm{~b}$ & $48.32 \mathrm{~b}$ & $22.78 \mathrm{a}$ & $13.78 \mathrm{a}$ & $100.96 \mathrm{~b}$ & $37.49 \mathrm{a}$ & $11.68 \mathrm{a}$ & $16.79 \mathrm{a}$ \\
\hline $\mathrm{CV}(\%)$ & 5.95 & 9.35 & 10.12 & 6.46 & 5.24 & 18.55 & 8.19 & 16.48 \\
\hline \multicolumn{9}{|c|}{ B-A } \\
\hline 0 & $29.33 \mathrm{a}$ & $32.03 \mathrm{a}$ & $12.94 \mathrm{a}$ & $7.69 \mathrm{a}$ & $35.36 \mathrm{a}$ & $24.95 \mathrm{a}$ & $5.84 \mathrm{a}$ & $6.52 \mathrm{a}$ \\
\hline 450 & $33.91 \mathrm{~b}$ & $37.33 \mathrm{~b}$ & $13.77 \mathrm{a}$ & $8.03 \mathrm{a}$ & $41.48 \mathrm{~b}$ & $25.36 \mathrm{a}$ & $6.26 \mathrm{a}$ & $6.78 \mathrm{a}$ \\
\hline$\overline{\mathrm{CV}(\%)}$ & 18.60 & 13.70 & 17.84 & 12.82 & 18.46 & 8.34 & 12.37 & 37.61 \\
\hline
\end{tabular}

${ }^{1}$ Corresponding to $\mathrm{N}$ applications of $6.03 \mathrm{~g} / \mathrm{plant}$ in Jan/2010 and $7.85 \mathrm{~g} / \mathrm{plant}$ in Dec/2010

Total height $(\mathrm{H})$; Height at the top of the canopy $(\mathrm{Hm})$; number of plagiotropic branches (NPBm); nodes of the orthotropic branch above the marked internode (NNOm); crown diameter (CD). Length (LPB), number of nodes (NRNm) and number of leaves (NLPm) of the the marked plagiotropic branch.

Means followed by the same letter in the column are not significantly different by the $\mathrm{F}$ test $(\mathrm{p} \geq 0.05)$.

Rev. Ceres, Viçosa, v. 60, n.6, p. 842-851, nov/dez, 2013 
indicating a negative effect of the compost on the leaf contents in the month following the fertilization, without C. juncea. Leaf contents decreased by $20 \%$, from 2.88 to $2.31 \%$, from the lowest to the highest compost rate.

\section{$N$ derived from green manure (NfGM) - Evaluation in April and June 2010}

There was significant effect $(\mathrm{p}<0.05)$ of the isolated factors of compost and sampling time on NfGM. NfGM decreased with increasing compost rates (Table 5), with reduction of $38.9 \%$ at the highest compost rate. Between the 3rd and 5th months after fertilization with $C$. juncea, there was an increase in NfGM and leaf percentage: in June 2010 was 34\% higher than in April 2010 (Table 5).

\section{Evaluation in December 2010 and in April 2011}

The $\mathrm{N}$ rate of the compost ranged from 25 to $100 \%$ and did not change the NfGM percentage, indicating that factors other than the amount of $\mathrm{N}$ applied interfered with leaf $\mathrm{N}$ of coffee. The NfGM percentage was higher in December 2010 compared with April 2011 (Table 5).

\section{Effect of fertilization with labeled $C$. juncea in December 2010}

The analysis of NfGM leaf percentage, as a function of compost rates, found no significant effect by the $\mathrm{F}$ test $(\mathrm{p} \geq$
$0.05)$, although the addition of $\mathrm{N}$ via compost has grown four-fold, from the lowest rate to the highest (Table 5).

\section{DISCUSSION}

\section{C. juncea decomposition}

The $\mathrm{T}_{1 / 2}$ of $\mathrm{N}-\mathrm{Cj}$ at 33.3 days is close to the results reported in the literature of 24 days (Diniz et al., 2007) and 28 days (Ribas et al., 2010) for gray velvet bean; 30, 56 and 32 days were reported for forage peanut, tropical kudzu and siratro, respectively (Espindola et al., 2006); and more than 15 days for C. juncea (Perin et al., 2006). Since $53 \%$ of the $\mathrm{N}$ is accumulated between February and May, during coffee bean development (Laviola et al., 2008), there may have been synchrony between $C$. juncea applied on January 29 and mineralization of 50 and $69.1 \%$ of $\mathrm{N}$, respectively, in the first and second month of bean development.

\section{Growth}

The rates of compost and $C$. juncea did not exert different responses on the growth in the two initial years, suggesting that $25 \%$ of the compost rate, with 7.5 and $5.25 \mathrm{~g} \mathrm{~N}$ per plant were enough for coffee. However, in April 2011, at the end of the fruiting period, there was response of coffee to $C$. juncea, indicating that the

Table 3. Total CEC in soil cultivated with coffee and fertilized with compost and Crotalaria juncea

\begin{tabular}{lcccc}
\hline C. juncea & \multicolumn{4}{c}{ Compost $(\boldsymbol{\%})$} \\
\cline { 2 - 5 }$($ g/plant) & $\mathbf{2 5}$ & $\mathbf{5 0}$ & $\mathbf{7 5}$ & $\mathbf{1 0 0}$ \\
\hline \multicolumn{4}{c}{ CEC total $\left(\mathbf{c m o l}_{\mathbf{c}} \mathbf{~ d m}^{-3}\right)$} \\
\hline 0 & $6.27 \mathrm{~b}$ & $6.95 \mathrm{a}$ & $7.05 \mathrm{~b}$ & $7.70 \mathrm{a}$ \\
\hline 50 & $7.12 \mathrm{a}$ & $7.15 \mathrm{a}$ & $7.97 \mathrm{a}$ & $7.77 \mathrm{a}$ \\
\hline
\end{tabular}

Means followed by the same letter in the column are not significantly different by the $\mathrm{F}$ test $(\mathrm{p} \geq 0.05)$.

Table 4. Leaf $\mathrm{N}$ in coffee trees fertilized with Crotalaria juncea dry matter, sampled in April, June and November, 2010 and April/ 2011 and $\mathrm{N}$ contents as function of compost and Crotalaria juncea rates sampled in November, 2010

\begin{tabular}{|c|c|c|c|c|}
\hline \multirow{2}{*}{$\begin{array}{l}\text { C. juncea }{ }^{1} \\
\text { (g/plant) }\end{array}$} & Apr/2010 & Jun/2010 & Nov/2010 & Apr/2011 \\
\hline & \multicolumn{4}{|c|}{$\mathbf{N}(\%)$} \\
\hline 450 & $2.67 \mathrm{a}$ & $2.70 \mathrm{a}$ & $2.51 \mathrm{a}$ & $2.12 \mathrm{a}$ \\
\hline 0.0 & $2.41 \mathrm{~b}$ & $2.58 \mathrm{a}$ & $2.60 \mathrm{a}$ & $2.01 \mathrm{a}$ \\
\hline \multirow[t]{2}{*}{$\mathrm{CV}(\%)$} & 9.45 & 7.59 & 8.84 & 7.22 \\
\hline & \multicolumn{4}{|c|}{ Compost $^{2}$} \\
\hline C.juncea & $25 \%$ & $50 \%$ & $75 \%$ & $100 \%$ \\
\hline (g/plant) & \multicolumn{4}{|c|}{$\mathbf{N}(\%)$} \\
\hline 450 & $2.46 \mathrm{~b}$ & $2.43 \mathrm{~b}$ & $2.44 \mathrm{a}$ & $2.72 \mathrm{a}$ \\
\hline 0.0 & $2.81 \mathrm{a}$ & $2.84 \mathrm{a}$ & $2.41 \mathrm{a}$ & $2.34 \mathrm{~b}$ \\
\hline
\end{tabular}

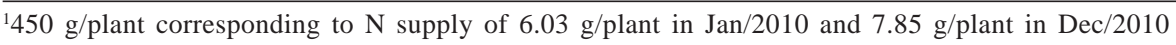

${ }^{2}$ Rates corresponding to $7.5 ; 15.0 ; 22.5$ and 30.0 g/plant of compost $\mathrm{N}$ applied in Nov/2010.

Means followed by different letters in the column are significantly different by the $\mathrm{F}$ test $(\mathrm{p}<0.05)$. 
compost only was not efficient to supply the nutritional demand. It is likely that the response to $C$. juncea fertilization was due to the increased demand during the fruiting period, with beans acting as strong nutrient sinks (Fenilli et al., 2007b; Laviola et al., 2008) and the plant simultaneously in vegetative and reproductive growth (Fenilli et al., 2007a).

Increased $\mathrm{H}, \mathrm{Hm}$ and $\mathrm{CD}$ with $C$. juncea fertilization suggest that there was an effect of the split fertilization, because $C$. juncea was applied 49 days after the compost. This complementation was of $7.8 \mathrm{~g} /$ plant of $\mathrm{N}$, compared with $21 \mathrm{~g} /$ plant at the highest compost rate.

Araujo et al. (2008) reported higher vegetative growth with rates of organic compost ranging from 0.702 to 0.770 $\mathrm{kg} /$ pot, in $10 \mathrm{dm}^{3}$ pots. These rates corresponded to $64-70$ $\mathrm{g}$ of $\mathrm{N}$ in $64 \mathrm{dm}^{3}$ holes, which were taken as reference values in this work. This correspondence was a high value for field conditions, because the application of $0.0175 \mathrm{~kg} /$ hole of $\mathrm{N}$ was not different from $0.07 \mathrm{~kg} / \mathrm{hole}$ and is close to the recommendation for Minas Gerais, which ranges from 0.009 to $0.025 \mathrm{~g} /$ plant (Guimarães et al., 1999).

The initial yield of processed coffee in this work, 7.9 bags ha-1 ${ }^{-1}$ is close to that obtained by other authors in the $1^{\text {st }}$ harvest, with $3.5,4.5$ and 9.6 bags ha $^{-1}$, respectively in coffee fertilized with gray velvet bean, leucaena and sugarcane filter cake (Fidalsky \& Chaves, 2010); 6.6, 9.1 and 12.1 bags ha $^{-1}$ in conventional crops (Carvalho et al., 2006) and 4.8 bags ha $^{-1}$ in irrigated conventional system with application of $280 \mathrm{~kg} \mathrm{ha}^{-1} \mathrm{~N}$ (Fenilli, 2006).

Table 5. Percentage of leaf $\mathrm{N}$ derived from Crotalaria juncea (NfGM) applied in January 2010, in coffee fertilized with compost, at four sampling times

\begin{tabular}{lc}
\hline \multicolumn{2}{c}{ Compost $^{1}$} \\
\hline \\
\hline Rate (\%) & N (g/plant) \\
\hline 25 & 7.5 \\
50 & 15.0 \\
75 & 22.5 \\
100 & 30.0 \\
\hline Mean & \\
\hline CV $(\%)$ & \\
\hline & \\
\hline Rate (\%) & \\
\hline 25 & \\
50 & 15.0 \\
75 & 22.5 \\
100 & 30.0 \\
\hline Mean & \\
\hline CV $(\%)$ & \\
\hline
\end{tabular}

\begin{tabular}{cc}
\multicolumn{3}{c}{ C. juncea applied in Jan/2010 } \\
\hline \multicolumn{3}{c}{ Evaluation times } \\
\hline Apr/2010 & Jun/2010 \\
\hline NfGM \% \\
\hline 8.15 & 11.56 \\
8.35 & 10.77 \\
4.98 & 6.76 \\
5.93 & 7.62 \\
\hline $6.85 \mathrm{a}$ & $9.18 \mathrm{~b}$ \\
\hline \multicolumn{3}{c}{} \\
\hline Dec/2010 & Apr/2011 \\
\hline 8.38 & NfGM \% \\
8.00 & \\
6.26 & 4.30 \\
6.99 & 4.38 \\
\hline $7.41 \mathrm{a}$ & 4.08 \\
\hline
\end{tabular}

\section{C. juncea applied in Dec/2010}

\section{Compost $^{2}$}

\begin{tabular}{lc} 
Rate $(\%)$ & N (g/plant) \\
\hline 25 & 7.5 \\
50 & 15.0 \\
75 & 22.5 \\
100 & 30.0 \\
\hline
\end{tabular}

\section{Mean}

CV $(\%)$

\begin{tabular}{cc}
\hline \multicolumn{3}{c}{ Evaluation times } \\
\hline Apr/2011 & - \\
\hline \multicolumn{3}{c}{ NfGM \% } \\
20.70 & - \\
16.43 & - \\
15.21 & - \\
\hline 17.93 & - \\
\hline 36.11 & - \\
\hline
\end{tabular}

${ }^{1}$ Compost applied in November 2009

${ }^{2}$ Compost applied in November 2010.

Fertilization with Crotalaria juncea (450 g/plant) corresponding to the $\mathrm{N}$ rate of $6.03 \mathrm{~g} / \mathrm{plant}$ in Jan/2010 and $7.85 \mathrm{~g} / \mathrm{plant}$ in Dec/2010. Means followed by different letters in the same row are significantly different by the $\mathrm{F}$ test $(\mathrm{p}<0.05)$. 


\section{Soil analysis}

Despite improvements in all indicators of soil quality with increasing compost rates, there was no response of coffee to yield gains as a function of the rates. This fact shows that the lowest compost rate was enough for the coffee tree to reach its yield potential at the $1^{\text {st }}$ harvest, at 27 months old.

The compost applied in 2010 was well cured and application of mature compost should be split, especially in perennial crops, to prevent leaching losses of ammonium and nitrate (Melo et al., 2008). In consequence, part of the compost $\mathrm{N}$, especially at higher rates, may have been lost by leaching or immobilized by soil organisms, whose populations tend to grow with the addition of organic material to the soil (Balota \& Chaves, 2010). Therefore, splitting of compost at higher rates might reduce potential losses and provide mineralized $\mathrm{N}$ at times of greatest demand, after flowering and at the pinhead stage, since the dry matter accumulation rate of beans increases up to the 3rd week of February (Fenilli et al., 2007b) and the highest $\mathrm{N}$ accumulation occurs at the stages of rapid expansion, between December and January, and bean-filling stage, between February and April (Laviola et al., 2008).

\section{Leaf $N$}

The highest leaf $\mathrm{N}$ content of coffee treated with $C$. juncea occurred only in April 2010 and can be related to rainfall distribution. Precipitation was lower in February 2010 (45.5 mm), increased in March (184.8 mm) and certainly enabled that the mineralized nutrients from organic matter were released to the soil and absorbed by the coffee tree.

After ten months (November 2010), following the $C$. juncea application, leaf concentrations of $\mathrm{N}$-compost at the rates of 25 and $50 \%$ were higher without the legume. However, at the rate of $100 \%$, the highest leaf $\mathrm{N}$ was recorded with $C$. juncea. Hence, there was a residual effect of $C$. juncea and a probable $\mathrm{N}$ immobilization by soil microorganisms to decompose this remaining organic matter, resulting in a reduction of leaf concentrations at the rates of 25 and $50 \%$.

In maize grown in pots and fertilized with $C$. juncea, there was no $\mathrm{N}$ immobilization caused by the legume, because of the relatively low C/N (Ambrosano et al., 2003 and 2009). However, maize is an annual and shortcycle crop and would be less influenced by the remaining and more recalcitrant organic matter. In this study, at 60 days after the $C$. juncea cutting, the dry matter and $\mathrm{N}$ remaining were 66.4 and $30.1 \%$, respectively, with $\mathrm{N}$ depletion in the remaining organic matter, which may have contributed to the $\mathrm{N}$ immobilization and reduced leaf content in December 2010.

The compost applied in November 2010 had pH 9.5; C/ $\mathrm{N}$ ratio of $8 / 1$ and $168 \mathrm{~g} \mathrm{~kg}^{-1}$ of organic carbon. These values are close to those indicated for mature compost parameters, with alkaline $\mathrm{pH}, \mathrm{C} / \mathrm{N}$ ratio and organic carbon adequate to N mineralization (Herberts et al., 2005; Silva et al, 2008; Silva et al., 2009b). Nevertheless, there was reduction in leaf $\mathrm{N}$ in the month subsequent to fertilization with increasing compost rates, which may be due to the initial $\mathrm{N}$ immobilization caused by the increase in microbial biomass (Herberts et al., 2005).

\section{Leaf $N$ derived from $C$. juncea in the first year of growth}

The decrease in NfGM of coffee leaves, from 9.96 to $6.08 \%$, with increasing compost rates, in April 2010, indicated a dilution effect. The decrease was small, despite the $\mathrm{N}-\mathrm{Cj}$ rate $(6.03 \mathrm{~g} / \mathrm{plant})$ has varied from 45 to $17 \%$ of the total $\mathrm{N}$ applied with the $\mathrm{N}$-compost. A greater variation was obtained in the aerial parts of maize fertilized with $1.0 \mathrm{~g}$ of $\mathrm{N}-\mathrm{Cj}$ per pot, with NfGM decreasing from 44.6 to $14.0 \%$ at rates of urea from 0.0 to $2.25 \mathrm{~g} / \mathrm{pot}$ (Smith et al., 2009b). The smaller variation in the percentage of NfGM with compost, in relation to urea, may be related to the increased availability of $\mathrm{N}$-urea, which is totally soluble, and the application of compost in a single dose 49 days before $C$. juncea, compared with the results of Smith et al. (2009b), who applied $C$. juncea together with the first dose of urea. This same reasoning can be applied to the results of $C$. juncea application in December 2010, two months after the compost application, which resulted in $17.9 \%$ of NfGM regardless of the compost rate, indicating no dilution of the $\mathrm{N}-\mathrm{Cj}$ by the $\mathrm{N}$-compost.

The increase in leaf NfGM in June 2010 compared with April 2010, suggests an increase in the availability of $\mathrm{N}-\mathrm{Cj}$ in the soil in relation to the organic compost. However, Ambrosano et al. (2009) reported values between 40 and $42.4 \%$ of $\mathrm{N}$ derived from aerial parts of $C$. juncea and velvet bean as the sole $\mathrm{N}$ source, in maize aerial parts at 20, 40, 60, 80 and 100 days after emergence. The differences observed are probably due to the two-month interval between the application of the compost and $C$. juncea, which increased the $\mathrm{N}$ available from $C$. juncea, the latest application.

Unlike what happens with green manure, in coffee fertilized with labeled ammonium sulfate, the leaf $\mathrm{N}$ from the fertilizer accounted for $24.4,40.7,44.8$ and $49.6 \%$ of the total $\mathrm{N}$ at $63,126,182$ and 263 days after anthesis (Fenilli et al., 2007a), indicating an increasing trend, which should be associated with the increased $\mathrm{N}$ availability in the soil after application of each portion of the fertilizer. These variations show that the separation of the application time of the compost and C. juncea can be beneficial for supplying $\mathrm{N}$ for coffee in a more distributed way. 


\section{Evaluation in the second year of growth (December 2010; April 2011)}

The reduction of NfGM in April 2011 compared with December 2010, from $7.41 \%$ to $4.15 \%$, is certainly related to the dilution of the ${ }^{15} \mathrm{~N}$ applied in January 2010, with the beginning of the compost fertilization in November 2010 and the $C$. juncea application in December 2010. Similarly, Ambrosano et al. (2011) obtained $4.1 \%$ of $\mathrm{N}-\mathrm{Cj}$ in sugarcane leaves in the $2^{\text {nd }}$ harvest after $C$. juncea application, indicating the persistence of residual $\mathrm{N}$ in the soil. Fenilli et al., (2008) found in the litter and in the soil $46.3 \%$ of applied $\mathrm{N}$ after a year of application of marked ammonium sulfate in a coffee plantation.

Araujo et al. (2005) reported 12.8\% of NfGM in wheat aerial parts, applying $100 \mathrm{~kg} \mathrm{~N} \mathrm{ha}^{-1}$ of $C$. juncea. Ovalle et al. (2010) applied $68-194 \mathrm{~kg} \mathrm{~N} \mathrm{ha}^{-1}$ with early and late legumes, respectively, supplementary to $40 \mathrm{~kg} \mathrm{ha}^{-1}$ mineral $\mathrm{N}$ and found in grapevine leaves, 14 to $20 \%$ of NfGM. Ambrosano et al. (2011) obtained 10.9\% of $\mathrm{N}$ derived from $C$. juncea in sugarcane leaves fertilized with $196 \mathrm{~kg}$ $\mathrm{N}-\mathrm{Cj} \mathrm{ha}{ }^{-1}$. The value found from the first application $(6.85 \%)$ is below the values found in the literature, but $17.93 \%$ from the second application is close to the results reported. Despite the large difference between the levels of $\mathrm{N}$ supplied by legumes in many studies, the percentage of $\mathrm{N}$ derived from the legumes in the leaves does not show a direct relationship with the dose applied, leading us to believe that other factors predominate in the dynamics of $\mathrm{N}$ mineralization and absorption. However, the factor fertilization time may have led to large differences in the $\mathrm{N}$ levels in the two consecutive years. In the first year, the application was carried out at the end of January, near the period of decreasing $\mathrm{N}$ accumulation by the coffee (Fenilli et al, 2007b; Laviola et al ,2008), unlike the second year in which $C$. juncea was applied in December, in the early stage of rapid expansion and increasing $\mathrm{N}$ accumulation.

\section{CONCLUSIONS}

Until flowering, the coffee tree does not show increased growth in response to supplementation of organic compost with aerial parts of Crotalaria juncea.

After the onset of the reproductive phase, the coffee tree has higher growth rate with the fertilization with aerial parts of Crotalaria juncea, supplementing the compost fertilization.

The organic compost increases $\mathrm{pH}, \mathrm{P}, \mathrm{K}, \mathrm{Ca}, \mathrm{Mg}$, sum of bases, effective CEC, base saturation and organic matter, and reduces the potential acidity.

The organic compound increases leaf $\mathrm{N}$ content in coffee trees.
When Crotalaria juncea is applied to coffee about two months after the organic compost, the ratio of leaf NfGM in coffee is independent of the compost rate.

The use of the isotope ${ }^{15} \mathrm{~N}$ allows the calculation of the NfGM contribution to the coffee tree, with percentages of leaf $\mathrm{N}$ derived from Crotalaria juncea ranging from 9.2 to $17.9 \%$.

\section{REFERENCES}

Aita C \& Giacomini SJ (2003) Decomposição e mineralização de nitrogênio de resíduos culturais de plantas de cobertura de solo solteiras e consorciadas. Revista Brasileira de Ciência do Solo, 27:601-612.

Ambrosano EJ, Trivelin PCO, Cantarella H, Ambrosano GMB \& Muraoka T (2003) Nitrogen mineralization in soils amended with sunnhemp, velvet bean and common bean residues. Scientia Agricola, 60:133-137.

Ambrosano EJ, Trivelin PCO, Cantarella H, Ambrosano GMB, Schammass EA, Muraoka T, Guirado N \& Rossi F (2009) Nitrogen supply to corn from sunn hemp and velvet bean green manures. Scientia Agricola, 66:386-394.

Ambrosano EJ, Trivelin PCO, Cantarella H, Ambrosano GMB, Schammass EA, Muraoka T \& Rossi F (2011) ${ }^{15} \mathrm{~N}$-labeled nitrogen from green manure and ammonium sulfate utilization by the sugarcane ratoon. Scientia Agricola, 68:361-368.

Araujo ASF, Teixeira GM, Campos AX, Silva FC, Ambrosano EJ \& Trivelin PCO (2005) Utilização de nitrogênio pelo trigo cultivado em solo fertilizado com adubo verde (Crotalaria juncea) e/ ou uréia. Ciência Rural, 35:284-289.

Araujo JBS, Carvalho GJ, Guimarães RJ \& Carvalho JG (2007) Composto orgânico e biofertilizante supermagro na formação de cafeeiros: teores foliares. Coffee Science, 2:20-28.

Araujo JBS, Carvalho GJ, Guimarães RJ, Morais AR \& Cunha RL (2008) Composto orgânico e biofertilizante supermagro na formação de cafeeiros. Coffee Science, 3:115-123.

Balota EL \& Chaves JCD (2010) Enzymatic activity and mineralization of carbon and nitrogen in soil cultivated with coffee and green manures. Revista Brasileira de Ciência do Solo, 34:1573-1583.

Bergo LC, Pacheco EP, Mendonça HA \& Marinho JTS (2006) Avaliação de espécies leguminosas na formação de cafezais no segmento da agricultura familiar no Acre. Acta Amazônica, 36:19-24.

Carvalho GR, Mendes ANG, Bartholo GF, Nogueira AM \& Amaral MA (2006) Avaliação de produtividade de progênies de cafeeiro em dois sistemas de plantio. Ciência e Agrotecnologia, 30:838843 .

Diniz ER, Santos RHS, Urquiaga SS, Peternelli LA, Barrella TP \& Freitas GB (2007) Gren manure incorporation timing for organically grown broccoli. Pesquisa Agropecuária Brasileira, 42:199-206

Espindola JAA, Guerra JGM, Almeida DL, Teixeira MG \& Urquiaga S (2006) Decomposição e mineralização de nutrientes acumulados em leguminosas herbáceas perenes consorciadas com bananeira. Revista Brasileira de Ciência do Solo, 30:321-328

Fenilli TAB (2006) Destino do nitrogênio $\left({ }^{15} \mathrm{~N}\right)$ fertilizante em uma cultura de café. Tese de Doutorado. Universidade de São Paulo, Piracicaba. 100p. 
Fenilli TAB, Reichardt K, Favarin JL, Bacchi OOS, Silva AL \& Timm LC (2008) Fertilizer ${ }^{15} \mathrm{~N}$ balance in a coffee cropping system: a case study in Brazil. Revista Brasileira de Ciência do Solo, 32:1459-1469.

Fenilli TAB, Reichardt K, Bacchi OOS, Trivelin PCO \& DouradoNeto D (2007a) The ${ }^{15} \mathrm{~N}$ isotope to evaluate fertilizer nitrogen absorption efficiency by the coffee plant. Anais da Academia Brasileira de Ciências, 79:767-776.

Fenilli TAB, Reichardt K, Dourado-Neto D, Trivelin PCO, Favarin JL, Costa FMP \& Bacchi OOS (2007b) Growth, development, and fertilizer- ${ }^{15} \mathrm{~N}$ recovery by the coffee plant. Scientia Agricola, 64:541-547.

Fidalsky J \& Chaves JCD (2010) Respostas do cafeeiro (Coffea arabica L.) IAPAR-59 à aplicação superficial de resíduos orgânicos em um latossolo vermelho distrófico típico. Coffee Science, 5:75-86

Guimarães PTG, Garcia AWR, Alvarez VH, Prezotti LC, Viana AS, Miguel AE, Malavolta E, Corrêa JB, Lopes AS, Nogueira FD, Monteiro Avo \& Oliveira JA (1999) Cafeeiro. In: Ribeiro AC, Guimarães PTG \& Alvarez VH (Eds.) Recomendações para o uso de Corretivos e Fertilizantes em Minas Gerais. 5a Aproximação. Viçosa, CSFSEMG/UFV. p.289-302.

Herberts RA, Coelho CRA, Miletti LC \& Mendonça MM (2005) Compostagem de resíduos sólidos orgânicos: aspectos biotecnológicos. Revista Saúde e Ambiente, 6:41-50.

Laviola BG, Martinez HEP, Salomão LCC, Cruz CD, Mendonça SM \& Rosado L (2008) Acúmulo em frutos e variação na concentração foliar de NPK em cafeeiro cultivado em quatro altitudes. Bioscience Journal, 24:19-31.

Martinez HEP \& Clemente JM (2011) O uso do cultivo hidropônico de plantas em pesquisa. Série didática. Viçosa, UFV. $76 \mathrm{p}$.

Melo LCA, Silva CA \& Dias BO (2008) Caracterização da matriz orgânica de resíduos de origens diversificadas. Revista Brasileira de Ciência do Solo, 32:101-110.

Ovalle C, Pozo A, Peoples MB \& Lavín A (2010) Estimating the contribution of nitrogen from legume cover crops to the nitrogen nutrition of grapevines using a ${ }^{15} \mathrm{~N}$ dilution technique. Plant Soil, 334:247-259.
Paul EA \& Clark FE (1996) Dynamics of residue decomposition and soil organic matter turnover. In: Paul, EA (Ed.) Soil microbiology and biochemistry. $2^{\mathrm{a}}$ ed. San Diego, Academic press. p.158-179.

Perin A, Santos RHS, Urquiaga SS, Cecon PR, Guerra GM \& Freitas GB (2006) Sunnhemp and millet as green manure for tropical maize production. Scientia Agricola, 63:453-459.

Ribas RGT, Santos RHS, Siqueira RG, Diniz ER, Peternelli LA \& Freitas GB (2010) Decomposição, liberação e volatilização de nitrogênio em resíduos culturais de mucuna-cinza (Мucuna cinerea). Ciência e Agrotecnologia, 34:878-885.

Ricci MSF, Alves BJR, Miranda SC \& Oliveira FF (2005) Growth rate and nutritional status of an organic coffee cropping system. Scientia Agricola, 62:138-144.

Silva EC, Muraoka T, Buzetti S, Veloso MEC \& Trivelin PCO (2006) Aproveitamento do nitrogênio $\left({ }^{15} \mathrm{~N}\right)$ da crotalaria e do milheto pelo milho sob plantio direto em Latossolo Vermelho de Cerrado. Ciência Rural, 36:739-746.

Silva AG, Leite VD, Silva MMP, Prasad S \& Feitosa WBS (2008) Compostagem de lodo de tanque séptico e resíduos vegetais. Engenharia Sanitária e Ambiental, 13:371-379.

Silva EC, Muraoka T, Villanueva FCA \& Espinal FSC (2009a) Aproveitamento de nitrogênio pelo milho, em razão da adubação verde, nitrogenada e fosfatada. Pesquisa Agropecuária Brasileira, 44:118-127.

Silva FAM, Villas Boas RL \& Silva RB (2009b) Parâmetros de maturação para diferentes compostos orgânicos. Revista Brasileira de Agroecologia. 4:67-78.

Silva FC (2009c) Manual de análises químicas de solos, plantas e fertilizantes. $2^{a}$ ed. Embrapa. 627p.

Snoeck D, Zapata F \& Domenach AM (2000) Isotopic evidence of the transfer of nitrogen fixed bylegumes to coffee trees. Biotechnology Agronomy Society and Environment, 4:95-100.

Vilela EF, Freitas MRC, Piano PB, Santos RHS \& Mendonça ES (2011) Crescimento inicial de cafeeiros e fertilidade do solo adubado com mucuna, amendoim forrageiro ou sulfato de amônio. Coffee Science, 6:27-35. 